\title{
Nocardia goodfellowii sp. nov. and Nocardia thraciensis sp. nov., isolated from soil
}

\author{
Anil Sazak, Nevzat Sahin and Mustafa Camas \\ Department of Biology, Faculty of Arts and Science, Ondokuz Mayis University, \\ 55139 Kurupelit-Samsun, Turkey
}

Correspondence

Anil Sazak

asazak@omu.edu.tr
The genus Nocardia belongs to the family Nocardiaceae, a member of the suborder Corynebacterineae, proposed by Stackebrandt et al. (1997), and members of the genus form extensively branched, substrate hyphae that fragment into rod-shaped, non-motile elements; aerial hyphae are usually formed but are sometimes only visible microscopically (Goodfellow \& Lechevalier, 1989; Gordon \& Mihm, 1957, 1962). Nocardiae are also characterized by a number of chemical markers, including the presence of meso-diaminopimelic acid in the whole peptidoglycan, arabinose and galactose as the characteristic sugars, mycolic acids with 40-60 carbon atoms and genomic DNA G + C contents of 64 to $72 \mathrm{~mol} \%$. The application of chemotaxonomic and molecular systematic methods has promoted a fundamental reassessment of the genus Nocardia (Trevisan, 1889; Lechevalier, 1976; Goodfellow, 1998). Much of the emphasis in nocardial systematics has focussed on the causal agents of actinomycetoma and nocardiosis (Goodfellow, 1992, 1998; McNeil \& Brown, 1994), although it is evident that nocardiae are common in natural habitats, notably soil (Orchard et al., 1977; Orchard, 1979, 1981; Wang et al., 1999; Maldonado et al., 2000). It is important to establish the species richness of Nocardia in natural habitats for ecological reasons and for industrial purposes, as novel members of the genus may be a source of

The GenBank/EMBL/DDBJ accession numbers for the $16 \mathrm{~S}$ rRNA gene sequences of Nocardia goodfellowii $\mathrm{A} 2012^{\top}$ and Nocardia thraciensis A2019 ${ }^{\top}$ are HQ157183 and HQ157184, respectively.

Five supplementary figures and three supplementary tables are available with the online version of this paper. commercially significant bioactive compounds such as nocardicin, tubelactomisin A and brasilicardin A (Aoki et al., 1976; Komaki et al., 1999; Igarashi et al., 2000). During the course of a screening programme designed to isolate novel actinomycetes from soil, two Nocardia-like strains, designated $\mathrm{A} 2012^{\mathrm{T}}$ and $\mathrm{A} 2019^{\mathrm{T}}$ were isolated and tentatively assigned to the genus Nocardia (Saintpierre, 2001). The aim of the present study was to establish the taxonomic position of the organisms; results indicate that the strains represent two novel species.

Strains $\mathrm{A} 2012^{\mathrm{T}}$ and $\mathrm{A} 2019^{\mathrm{T}}$ were isolated from a suspension of an arid soil that was used to inoculate Gauze medium no. 2 (Gauze et al., 1957) supplemented with cycloheximide $\left(50 \mu \mathrm{g} \mathrm{ml}^{-1}\right)$, nystatin $\left(50 \mu \mathrm{g} \mathrm{ml}^{-1}\right)$, nalidixic acid $\left(10 \mu \mathrm{g} \mathrm{ml}^{-1}\right)$ and novobiocin $\left(10 \mu \mathrm{g} \mathrm{ml}^{-1}\right)$ and incubated at $28{ }^{\circ} \mathrm{C}$ for 14 days. Soil samples were collected in the village of Sinankoy, in Edirne, Turkey. The isolates were purified and maintained on modified Bennett's agar (MBA; Jones, 1949) and preserved as a suspension of mycelial fragments in glycerol $(20 \%, \mathrm{w} / \mathrm{v})$ at $-20{ }^{\circ} \mathrm{C}$.

The morphological and physiological characteristics of strains $\mathrm{A} 2012^{\mathrm{T}}, \mathrm{A} 2019^{\mathrm{T}}$, Nocardia caishijiensis DSM $44831^{\mathrm{T}}$, Nocardia alba DSM $44684^{\mathrm{T}}$, Nocardia mexicana DSM $44952^{\mathrm{T}}$, Nocardia terpenica DSM $44935^{\mathrm{T}}$, Nocardia takedensis DSM $44801^{\mathrm{T}}$ and the type species of the genus Nocardia, Nocardia asteroides ATCC $19247^{\mathrm{T}}$ were studied after incubation for 14 days at $28{ }^{\circ} \mathrm{C}$ on various media described by Shirling \& Gottlieb (1966): yeast extract-malt extract agar (ISP 2), oatmeal agar (ISP 3), inorganic salt-starch agar (ISP 4), 
glycerol-asparagine agar (ISP 5), peptone-yeast extract-iron agar (ISP 6), tyrosine agar (ISP 7), MBA (Jones, 1949) and nutrient agar (NA; Difco). Growth was tested at various temperatures $\left(4,10,20,25,28,30,37\right.$ and $\left.45^{\circ} \mathrm{C}\right), \mathrm{pH}$ values $(4,5,6,7,8,9,10$ and 11$)$ and $\mathrm{NaCl}$ concentrations $(1-5 \%$, w/v) using ISP 2 as the basal medium. Gram staining was examined by using Hucker's method (Gerhardt, 1981). Acid-alcohol-fastness was examined by using Ziehl-Neelsen method (Gordon, 1967). Colony morphology and micromorphological properties of isolates $\mathrm{A} 2012^{\mathrm{T}}$ and $\mathrm{A} 2019^{\mathrm{T}}$ were determined by examination of gold-coated dehydrated specimens of 14 day cultures from ISP 2 medium (Fig. S1, available in IJSEM Online) using a Cambridge Stereoscan 240 instrument. The test strains were examined for a range of phenotypic properties using well-established procedures (Gordon et al., 1974; Williams et al., 1983; Isik et al., 1999).

Preparation of genomic DNA and PCR amplification of the 16S rRNA gene were carried out following Chun \& Goodfellow (1995). Nearly complete 16S rRNA gene sequences were determined for strains $\mathrm{A} 2012^{\mathrm{T}}$ (1469 bp) and $\mathrm{A} 2019^{\mathrm{T}}$ (1482 bp) by using an ABI PRISM 3730XL automatic sequencer. The identification of phylogenetic neighbours and the calculation of pairwise 16S rRNA gene sequence similarities were achieved using the EzTaxon server (http://www.eztaxon.org/; Chun et al., 2007). CLUSTAL W version 1.8 (Thompson et al., 1994) was used to align the sequences of strains $\mathrm{A} 2012^{\mathrm{T}}$ and $\mathrm{A} 2019^{\mathrm{T}}$ with those of related taxa retrieved from public databases. Phylogenetic trees were inferred using the neighbourjoining (Saitou \& Nei, 1987) and maximum-parsimony (Fitch, 1971) tree-making algorithms from the program MEGA version 3 (Kumar et al., 2004), and the maximumlikelihood method (Felsenstein, 1981) from the PHYLIP suite of programs (Felsenstein, 1993). The evolutionary distance model of Jukes \& Cantor (1969) was used to generate evolutionary distance matrices for the neighbour-joining algorithm. Topologies of the resultant trees were evaluated in a bootstrap analysis (Felsenstein, 1985) based on 1000 resamplings of the neighbour-joining dataset using the CONSENSE and SEQBOOT options from the PHYLIP package.

DNA-DNA relatedness values between strain $\mathrm{A} 2012^{\mathrm{T}}$ and related type species of $N$. caishijiensis DSM $44831^{\mathrm{T}}$, and between strain $\mathrm{A} 2019^{\mathrm{T}}$ and $N$. mexicana DSM $44952^{\mathrm{T}}$ were performed by the Identification Service at the Deutsche Sammlung von Mikroorganismen und Zellkulturen (DSMZ, Braunschweig, Germany). DNA was isolated using a French pressure cell (Thermo Spectronic) and was purified by chromatography on hydroxyapatite as described by Cashion et al. (1977). DNA-DNA hybridization was carried out as described by De Ley et al. (1970) [incorporating the modifications described by Huß et al. (1983)] using a model Cary 100 Bio UV/VIS-spectrophotometer equipped with a Peltier-thermostatted $6 \times 6$ multicell changer and a temperature controller with in situ temperature probe (Varian).
Freeze-dried cells used for chemotaxonomic analyses were obtained from cultures grown in glucose-yeast extract-malt extract (GYM) broth on a rotary shaker at 160 r.p.m. at $28{ }^{\circ} \mathrm{C}$ for 14 days, checked for purity, harvested by centrifugation and stored at room temperature until required. The isomers of diaminopimelic acid in the cell wall and whole cell-wall sugars were determined by the method of Staneck \& Roberts (1974). Isoprenoid quinones were extracted by the method of Collins et al. (1977) and were analysed by HPLC (Wu et al., 1989). Mycolic acids were prepared according to the methods of Minnikin et al. (1980). Fatty acids were determined from cells grown for 5 days in trypticase soy broth (TSB) at $28{ }^{\circ} \mathrm{C}$ with shaking at 150 r.p.m. After 5 days of incubation, $5 \mathrm{ml}$ starter culture was inoculated into $50 \mathrm{ml}$ TSB. The inoculated flask was incubated as before for 5 days. After harvesting by cellulose membrane filtration $(0.45 \mu \mathrm{m})$, wet cells $(200 \mathrm{mg}$ ) were placed in an extraction tube. Cellular fatty acids were extracted, derivatized to their fatty acid methyl esters and separated by the Microbial Identification System (MIDI; Microbial ID Inc.), utilizing an Agilent Technologies 6890N GC with a G2614A autosampler and a 6783 injector (Sasser, 1990; Kämpfer \& Kroppenstedt, 1996). Fatty acid methyl ester peaks were analysed using software version TSBA 5.0.

The DNA G + C contents of strains $A 2012^{\mathrm{T}}$ and $\mathrm{A} 2019^{\mathrm{T}}$ were determined following the procedure developed by Gonzalez \& Saiz-Jimenez (2005).

Strains $\mathrm{A} 2012^{\mathrm{T}}$ and $\mathrm{A} 2019^{\mathrm{T}}$, isolated from arid soil, grew well on various inorganic or organic media; vegetative and aerial mycelium grew well on the media tested. Table 1 shows the degree of growth and colour of both aerial and vegetative hyphae of isolates and members of the most closely related species.

The chemotaxonomic and morphological characteristics of the two isolates were consistent with their assignment to the genus Nocardia (Goodfellow, 1998; Goodfellow et al., 1999). Both strains contained galactose and arabinose as characteristic whole sugars plus glucose, mannose and ribose, in addition to meso-diaminopimelic acid as the dominant cell-wall diamino acid (chemotype IV sensu Lechevalier \& Lechevalier, 1980). The predominant menaquinone of strains $\mathrm{A} 2012^{\mathrm{T}}$ and $\mathrm{A} 2019^{\mathrm{T}}$ was MK- $8\left(\mathrm{H}_{4} \omega\right.$-cycl) (60 and $80 \%$, respectively), although substantial amounts of MK-9 (25 and 7.0\%, respectively), an unknown component $(8.0 \%)$ and traces of other menaquinones were present (Figs S2 and S3, available in IJSEM Online). The mycolic acid chain-length ranged from $\mathrm{C}_{48}$ to $\mathrm{C}_{58}$ for strain $\mathrm{A} 2012^{\mathrm{T}}$ and from $\mathrm{C}_{54}$ to $\mathrm{C}_{62}$ for strain $\mathrm{A}_{2019^{\mathrm{T}}}$ (Table S1, available in IJSEM Online). The fatty acid patterns of strains $\mathrm{A} 2012^{\mathrm{T}}$ and $\mathrm{A} 2019^{\mathrm{T}}$ were composed of straight-chain saturated and unsaturated fatty acids plus tuberculostearic acid (10-methyl octadecanoic acid) (Table S2, available in IJSEM Online) although there are qualitative and quantitative differences between the strains. 
Table 1. Growth and cultural characteristics of strains $A 2012^{\top}$ and $A 2019^{\top}$ and their closest neighbours

Strains: 1 , A2012 ${ }^{\mathrm{T}}$; 2, N. caishijiensis DSM 44831 ${ }^{\mathrm{T}}$; 3, A2019 ${ }^{\mathrm{T}}$; 4, N. mexicana DSM $44952^{\mathrm{T}}$. +++ , Abundant; ++ , moderate; + , poor.

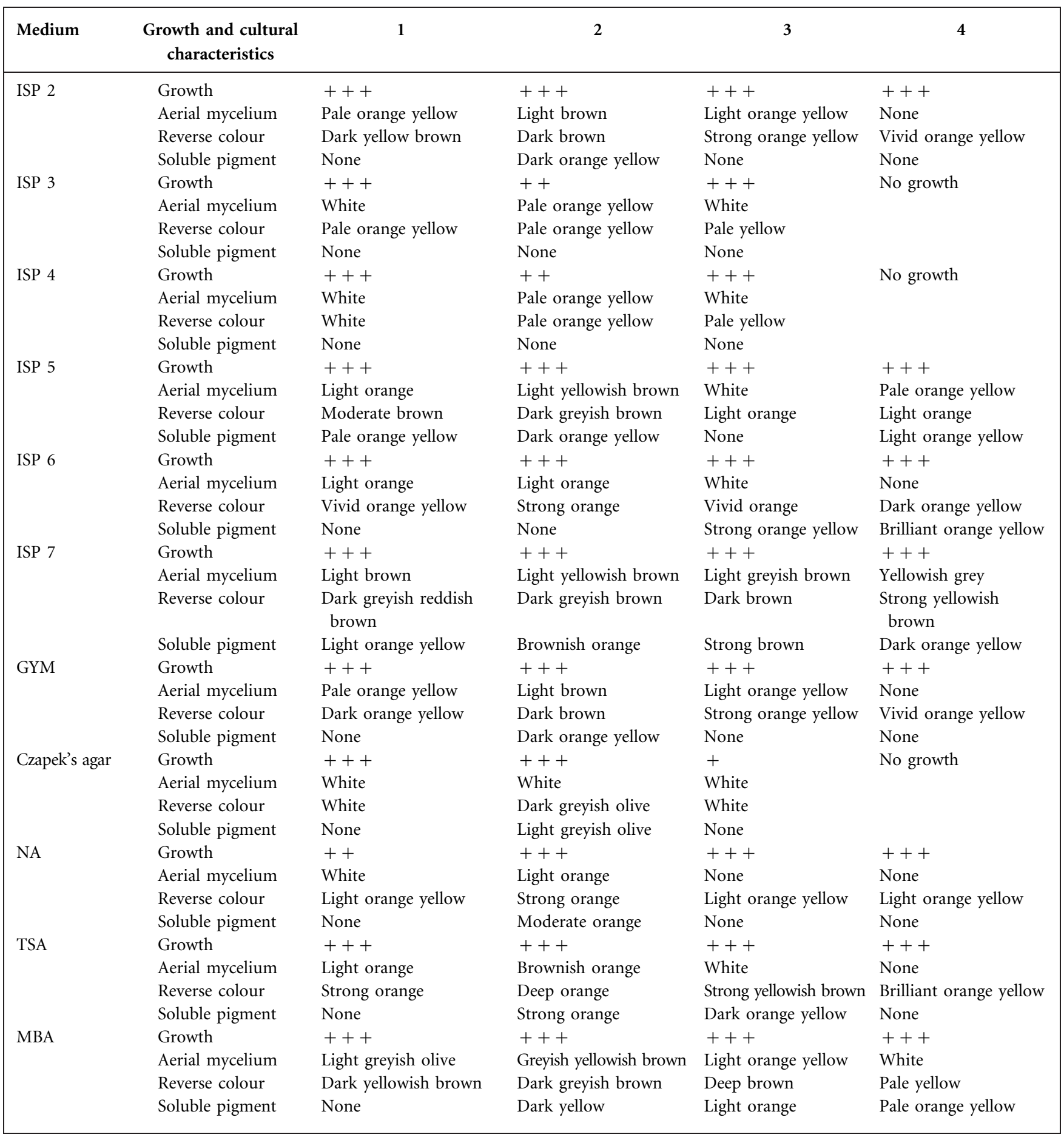

The genomic DNA G $+\mathrm{C}$ contents of strains $\mathrm{A} 2012^{\mathrm{T}}$ and $\mathrm{A} 2019^{\mathrm{T}}$ were 70.6 and $69.5 \mathrm{~mol} \%$, respectively.

Comparison of the almost-complete 16S rRNA gene sequences of isolates $\mathrm{A} 2012^{\mathrm{T}}$ and $\mathrm{A} 2019^{\mathrm{T}}$ with corresponding sequences from representatives of genera in the suborder Corynebacterineae, with the exception of position
600-638 (U:G) for strain $A 2019^{\mathrm{T}}, 843(\mathrm{U})$ for strains $\mathrm{A} 2012^{\mathrm{T}}$ and $\mathrm{A} 2019^{\mathrm{T}}$ and $1008-1021(\mathrm{~A}: \mathrm{U})$ for strain $\mathrm{A} 2012^{\mathrm{T}}$ according to the Escherichia coli numbering system, revealed the presence of signature nucleotides (Table S3, available in IJSEM Online) that are characteristic for members of the family Nocardiaceae (Stackebrandt et al., 1997) and the genus Nocardia (Chun \& Goodfellow, 1995). 


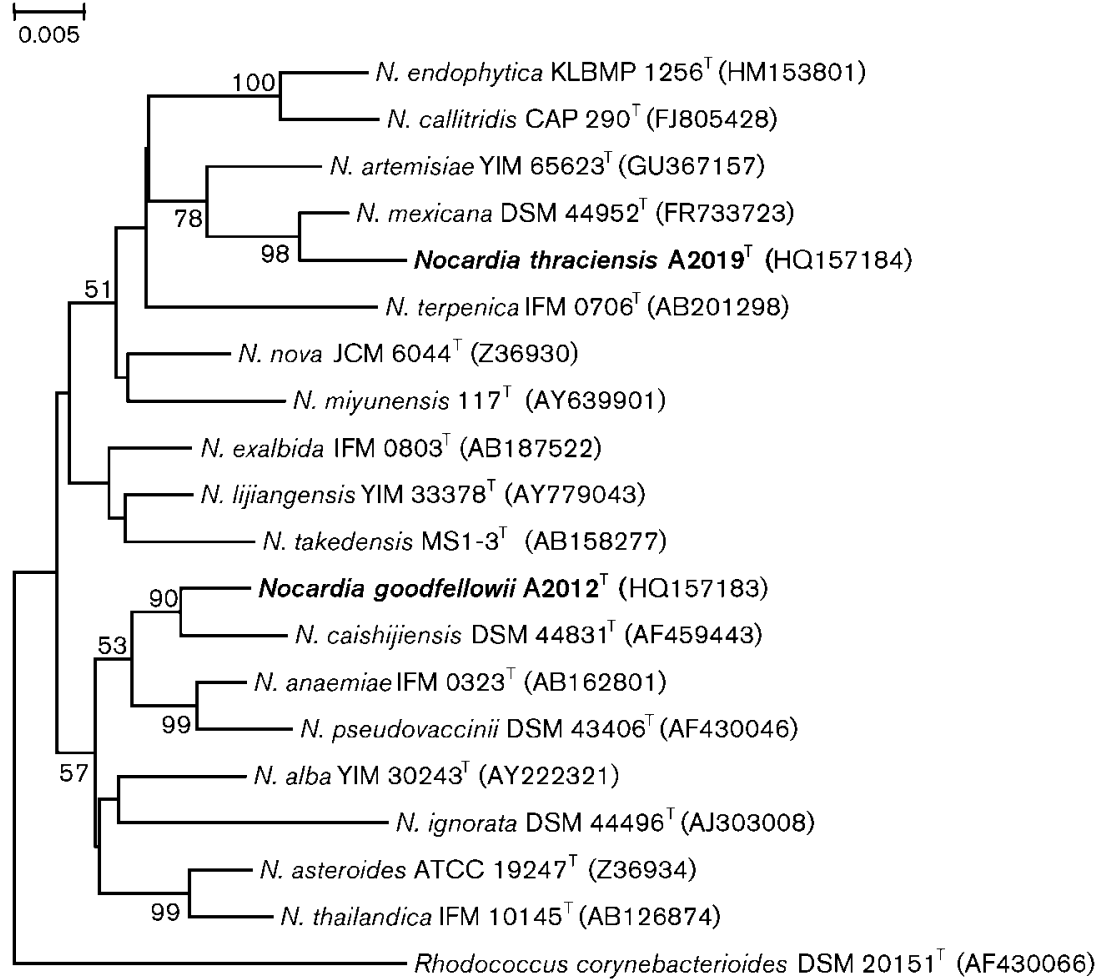

Fig. 1. Neighbour-joining tree (Saitou \& Nei, 1987) based on almost complete 16S rRNA gene sequences showing the positions of strains $\mathrm{A} 2012^{\top}$ and $\mathrm{A} 2019^{\top}$ among their nearest neighbours. Numbers at the nodes indicate the levels of bootstrap support (\%); only values above $50 \%$ are cited. GenBank accession numbers are given in parentheses. Bar, 0.005 substitutions per site. The root position of the neighbour-joining tree was obtained using Rhodococcus corynebacterioides DSM $20151^{\top}$ as the outgroup.
16S rRNA gene sequence similarities between strains $\mathrm{A} 2012^{\mathrm{T}}$ and the closely related type strains $N$. caishijiensis DSM $44831^{\mathrm{T}}$, N. alba YIM $30243^{\mathrm{T}}$, Nocardia anaemiae IFM $0323^{\mathrm{T}}$, Nocardia pseudovaccinii DSM $43406^{\mathrm{T}}, N$. asteroides ATCC $19247^{\mathrm{T}}$, Nocardia nova JCM $6044^{\mathrm{T}}$, Nocardia ignorata DSM $44496^{\mathrm{T}}$, Nocardia thailandica IFM $10145^{\mathrm{T}}$ and Nocardia cyriacigeorgica DSM $44484^{\mathrm{T}}$ were $98.6 \%$ (20 nt differences at 1426), 97.9\% (30 nt differences at 1442), 97.9\% (31 nt differences at 1469), 97.8\% (31 nt differences at 1455), $97.8 \%$ (32 nt differences at 1455), 97.8\% (32 nt differences at 1455), 97.5\% (36 nt differences at 1460), 97.5\% (36 nt differences at 1430) and $97.5 \%$ (37 nt differences at 1457), respectively.

Strain $\mathrm{A} 2019^{\mathrm{T}}$ was most closely related to N. mexicana CIP $108295^{\mathrm{T}}$; the two strains shared $98.94 \% 16 \mathrm{~S}$ rRNA gene sequence similarity, which corresponds to $14 \mathrm{nt}$ differences at 1329 locations. Relatively high similarity values were shown with the type strains of Nocardia artemisiae YIM $65623^{\mathrm{T}}(97.4 \% ; 39 \mathrm{nt}$ differences at 1468), N. terpenica IFM $0706^{\mathrm{T}}(97.3 \% ; 40 \mathrm{nt}$ differences at 1468), $N$. takedensis MS1-3 ${ }^{\mathrm{T}}(97.2 \%$; $40 \mathrm{nt}$ differences at 1448), Nocardia lijiangensis YIM $33378^{\mathrm{T}}$ (97.2\%; 41 nt differences at 1468) and Nocardia endophytica KLBMP $1256^{\mathrm{T}}$ (97.2\%; $41 \mathrm{nt}$ differences at 1459). It is also apparent from Fig. 1 that strains $\mathrm{A} 2012^{\mathrm{T}}$ and $\mathrm{A} 2019^{\mathrm{T}}$ are part of two different subclades and shared $95.8 \% \quad 16 \mathrm{~S}$ rRNA gene sequence similarity, which corresponds to $58 \mathrm{nt}$ differences at 1460 locations. It is clear from the phylogenetic analysis that strains $\mathrm{A} 2012^{\mathrm{T}}$ and $\mathrm{A} 2019^{\mathrm{T}}$ formed two distinct phyletic lines, with $N$. caishijiensis DSM $44831^{\mathrm{T}}$ and $N$. mexicana DSM $44952^{\mathrm{T}}$, respectively, in the Nocardia $16 \mathrm{~S}$ rRNA gene tree (Fig. 1; Figs S4 and S5, available in IJSEM Online). This was supported by all four tree-making algorithms and by a $100 \%$ bootstrap value.

The taxonomic integrity of the test strains was supported by DNA relatedness data. Strain $\mathrm{A} 2012^{\mathrm{T}}$ showed a DNA relatedness value of $15.4 \%$ to $N$. caishijiensis DSM $44831^{\mathrm{T}}$, whereas strain $\mathrm{A} 2019^{\mathrm{T}}$ showed a DNA relatedness value $27.2 \%$ to $N$. mexicana DSM $44952^{\mathrm{T}}$. On the other hand, the DNA relatedness value between $\mathrm{A} 2012^{\mathrm{T}}$ and $\mathrm{A} 2019^{\mathrm{T}}$ was $22.6 \%$. The phenotypic properties of these two strains also clearly distinguished them from each other and from the most closely related members of the genus Nocardia (Table 2).

It is evident from the genotypic and phenotypic data that isolates $\mathrm{A} 2012^{\mathrm{T}}$ and $\mathrm{A} 2019^{\mathrm{T}}$ represent two novel species within the genus Nocardia. It is, therefore, proposed that these organisms be classified in this taxon as Nocardia goodfellowii sp. nov. and Nocardia thraciensis sp. nov.

\section{Description of Nocardia goodfellowii sp. nov.}

Nocardia goodfellowii (good.fel.low'i.i. N.L. gen. masc. n. goodfellowii of Goodfellow, named in honour of Michael Goodfellow for his contributions to Nocardia systematics).

Aerobic, Gram-positive, weakly acid-alcohol-fast and nonmotile actinomycete that forms white or yellow to brown 
Table 2. Phenotypic properties that differentiate strains $A 2012^{\top}$ and $A 2019^{\top}$ and representatives of the phylogenetically most closely related species

Strains: 1, A2012 ${ }^{\mathrm{T}} ; 2$, N. caishijiensis DSM $44831^{\mathrm{T}} ; 3$, N. alba DSM $44684^{\mathrm{T}} ; 4$, N. anaemiae DSM $44821^{\mathrm{T}}$ [data taken from Kageyama et al. $(2005)$ ]; 5, N. asteroides ATCC $19247^{\mathrm{T}} ; 6$, A2019 ${ }^{\mathrm{T}} ; 7$, N. mexicana DSM $44952^{\mathrm{T}} ; 8$, N. terpenica DSM $44935^{\mathrm{T}} ; 9$, N. takedensis DSM $44801^{\mathrm{T}}$. Data from this study except where specified. ND, Not determined; +, positive; - , negative.

\begin{tabular}{|c|c|c|c|c|c|c|c|c|c|}
\hline Characteristic & 1 & 2 & 3 & 4 & 5 & 6 & 7 & 8 & 9 \\
\hline Aesculin & + & - & ND & ND & + & + & + & + & + \\
\hline Allantoin & - & - & $\mathrm{ND}$ & ND & + & + & - & - & $\mathrm{ND}$ \\
\hline Nitrate & + & + & + & ND & + & - & + & - & ND \\
\hline \multicolumn{10}{|l|}{ Degradation of: } \\
\hline DNA $(0.5 \%)$ & - & - & - & ND & - & - & - & + & - \\
\hline Gelatine $(0.5 \%)$ & + & + & + & ND & - & + & - & + & - \\
\hline Hypoxanthine $(0.4 \%)$ & + & - & - & + & - & + & + & - & - \\
\hline Starch $(1 \%)$ & - & - & - & ND & - & - & - & - & + \\
\hline Tween $20(1 \%)$ & - & - & - & ND & + & + & + & - & + \\
\hline Uric acid & + & + & + & + & - & + & + & + & - \\
\hline \multicolumn{10}{|c|}{ Growth on sole carbon sources $(1.0 \%, \mathrm{w} / \mathrm{v})$ : } \\
\hline Dextrin & - & + & - & ND & - & + & + & + & - \\
\hline Galactose & + & - & - & + & - & + & + & - & - \\
\hline Inositol & - & - & - & - & - & - & + & + & - \\
\hline Mannitol & + & + & - & ND & + & + & + & + & + \\
\hline Melezitose & - & - & - & ND & - & + & + & + & + \\
\hline Rhamnose & - & - & + & - & - & + & + & - & + \\
\hline Salicin & - & - & - & ND & - & + & + & + & - \\
\hline Sorbitol & + & - & - & + & - & + & + & + & - \\
\hline Starch & - & + & - & ND & - & + & + & - & + \\
\hline Sucrose & - & + & - & ND & + & + & + & - & + \\
\hline Xylitol & - & - & - & ND & - & - & + & + & + \\
\hline \multicolumn{10}{|l|}{ Growth at/in: } \\
\hline $10{ }^{\circ} \mathrm{C}$ & + & + & $\mathrm{ND}$ & ND & ND & - & - & - & $\mathrm{ND}$ \\
\hline pH 10.0 & + & + & $\mathrm{ND}$ & ND & + & - & + & - & ND \\
\hline $\mathrm{NaCl}(4.0 \%)$ & + & + & $\mathrm{ND}$ & ND & $\mathrm{ND}$ & - & + & - & $\mathrm{ND}$ \\
\hline
\end{tabular}

aerial mycelium, depending on the culture medium, that fragments into rod-shaped elements. Produces orangeyellow diffusible pigments on ISP 5 and ISP 7 media. Grows at $\mathrm{pH} 5.0-10.0$ and $10-37^{\circ} \mathrm{C}$, but not at $\mathrm{pH} 4.0$ or 11.0 , or at temperatures of 4 or $45{ }^{\circ} \mathrm{C}$. Optimal growth is at $28{ }^{\circ} \mathrm{C}$ and $\mathrm{pH}$ 7.0. Growth is observed in $0-4 \%(\mathrm{w} / \mathrm{v})$ $\mathrm{NaCl}$. Aesculin and arbutin are hydrolysed and nitrate is reduced but not allantoin. Degrades gelatin, hypoxanthine and uric acid but not adenine, casein, chitin, DNA, guanine, RNA, Tweens 20 and 80, xanthine and xylan. Assimilates adonitol, (-)-D-fructose, (+)-D-galactose,
(+)-D-glucose, (+)-D-mannose, (+ )-D-mannitol, maltose, propionic acid, $(-)$-D-sorbitol and succinic acid but not methyl $\alpha$-D-glucoside, $(-)$-D-arabinose, $(-)$-D-cellobiose, (-)-D-salicin, (+ )-D-melezitose, (+ )-D-melibiose, dextran, dextrin, inulin, $(-)$-L-sorbose, $(+)$-L-arabinose, (+)-L-rhamnose, lactose, L-glutamate, myo-inositol, raffinose, sucrose, xylitol or xylose as sole carbon sources. Utilizes $\alpha$-isoleucine, L-alanine, L-arginine, L-cysteine, Lhistidine, L-proline, L-serine, L-tyrosine and $\mathrm{L}$-valine but not D-phenylalanine, glycine, L-hydroxyproline, L-methionine or Lthreonine as sole nitrogen sources. Predominant menaquinone 
is MK-8 $\left(\mathrm{H}_{4} \omega\right.$-cycl $)(60 \%)$, although substantial amounts of MK-9 (25\%) and other components are also present. The major fatty acids are hexadecanoic acid, oleic acid and tuberculostearic acid [10-methyl branched $\mathrm{C}_{18: 0}$ ]. Mycolic acids with $48-56$ carbons are present.

The type strain, A2012 ${ }^{\mathrm{T}} \quad\left(=\mathrm{DSM} \quad 45516^{\mathrm{T}}=\mathrm{NRRL} \quad \mathrm{B}-\right.$ $24833^{\mathrm{T}}=$ KCTC $19986^{\mathrm{T}}$ ) was isolated from arid soil from Sinankoy, Lalapasa, Edirne, Turkey. The genomic DNA $\mathrm{G}+\mathrm{C}$ content of the type strain is $70.6 \mathrm{~mol} \%$.

\section{Description of Nocardia thraciensis sp. nov.}

Nocardia thraciensis (thra.ci.en'sis. N.L. fem. adj. thraciensis from Thrace, the European region of Turkey, the source of the organism).

Aerobic, Gram-positive, partially acid-alcohol-fast, nonmotile actinomycete that forms white aerial mycelium on ISP 3, ISP 4, ISP 5, ISP 6, Czapek's and TSA media, yellow to brown substrate mycelium depending on the culture medium that fragments into rod-shaped elements, and orange-yellow to strong brown soluble pigments produced on ISP 6, ISP 7, TSA and MBA media. Growth occurs at $\mathrm{pH} 6.0-9.0$ and $20-37{ }^{\circ} \mathrm{C}$ but not at $\mathrm{pH} 4.0,5.0$ or 10.0 , or at temperatures of 4,10 and $45{ }^{\circ} \mathrm{C}$. Optimal growth occurs at $\mathrm{pH} 7.0$ and $28{ }^{\circ} \mathrm{C}$. Growth is observed in $0-4 \%(\mathrm{w} / \mathrm{v})$ $\mathrm{NaCl}$. Aesculin, allantoin, arbutin and urea are hydrolysed but nitrate is not reduced. Degrades gelatin, hypoxanthine, Tween 20 and uric acid but not adenine, casein, chitin, DNA, guanine, RNA, Tween 80 , xanthine or xylan. Utilizes methyl $\alpha$-D-glucoside, $(-)$-D-fructose, $(-)$-D-salicin, $(+)$ D-galactose, (+ )-D-glucose, (+ )-D-mannose, (+ )-D-mannitol, dextrin, maltose, propionic acid, $(-)$-D-sorbitol, succinic acid, (+)-L-arabinose, (+)-L-rhamnose, (+)-Dmelezitose, sucrose and xylose but not adonitol, (-)-Darabinose, (-)-D-cellobiose, (+)-D-melibiose, dextran, inulin, (-)-L-sorbose, lactose, L-glutamate, myo-inositol, raffinose or xylitol as sole carbon sources. Utilizes $\alpha$ isoleucine, glycine, L-alanine, L-arginine, L-cysteine, Lhistidine, L-proline, L-serine, L-tyrosine and L-valine but not D-phenylalanine, L-hydroxyproline, L-methionine or L-threonine as sole nitrogen sources. Predominant menaquinone is $\mathrm{MK}-8\left(\mathrm{H}_{4} \omega-\mathrm{cycl}\right)(80 \%)$, although substantial amounts of MK-9 (7\%), an unknown component $(8 \%)$ and other menaquinones are also present The major fatty acids are hexadecanoic acid, oleic acid and tuberculostearic acid [10-methyl branched $\left.\mathrm{C}_{18: 0}\right]$. Mycolic acids with 54-62 carbons are present.

The type strain, A2019 $\left(=\mathrm{DSM} \quad 45517^{\mathrm{T}}=\mathrm{NRRL}\right.$ B$24834^{\mathrm{T}}=$ KCTC $19985^{\mathrm{T}}$ ), was isolated from arid soil in Sinankoy, Lalapasa, Edirne, Turkey. The genomic DNA $\mathrm{G}+\mathrm{C}$ content of the type strain is $69.5 \mathrm{~mol} \%$.

\section{Acknowledgements}

This research was supported by Ondokuz Mayis University (OMU), project no. PYO.FEN. 1901.09.003.

\section{References}

Aoki, H., Sakai, H., Kohsaka, M., Konomi, T., Hosoda, J., Kubochi, Y., Iguchi, E. \& Imanaka, H. (1976). Nocardicin A, a new monocyclic beta-lactam antibiotic. I. Discovery, isolation and characterization. J Antibiot (Tokyo) 29, 492-500.

Cashion, P., Holder-Franklin, M. A., McCully, J. \& Franklin, M. (1977). A rapid method for the base ratio determination of bacterial DNA. Anal Biochem 81, 461-466.

Chun, J. \& Goodfellow, M. (1995). A phylogenetic analysis of the genus Nocardia with 16S rRNA gene sequences. Int J Syst Bacteriol 45, 240-245.

Chun, J., Lee, J.-H., Jung, Y., Kim, M., Kim, S., Kim, B. K. \& Lim, Y. W. (2007). EzTaxon: a web-based tool for the identification of prokaryotes based on $16 \mathrm{~S}$ ribosomal RNA gene sequences. Int J Syst Evol Microbiol 57, 2259-2261.

Collins, M. D., Pirouz, T., Goodfellow, M. \& Minnikin, D. E. (1977). Distribution of menaquinones in actinomycetes and corynebacteria. J Gen Microbiol 100, 221-230.

De Ley, J., Cattoir, H. \& Reynaerts, A. (1970). The quantitative measurement of DNA hybridization from renaturation rates. Eur $J$ Biochem 12, 133-142.

Felsenstein, J. (1981). Evolutionary trees from DNA sequences: a maximum likelihood approach. J Mol Evol 17, 368-376.

Felsenstein, J. (1985). Confidence limits on phylogenies: an approach using the bootstrap. Evolution 39, 783-791.

Felsenstein, J. (1993). PHYLIP (phylogeny inference package), version 3.5c. Distributed by the author. Department of Genome Sciences, University of Washington, Seattle, USA.

Fitch, W. M. (1971). Toward defining the course of evolution: minimum change for a specific tree topology. Syst Zool 20, 406-416.

Gauze, G. F., Preobrazhenskaya, T. P., Kudrina, E. S., Blinov, N. O., Ryabova, I. D. \& Sveshnikova, M. A. (1957). Problems of Classification of Actinomycete-Antagonists. Moscow: Government Publishing House of Medical Literature, Mediz.

Gerhardt, P. (1981). Manual of Methods for General Bacteriology. Washington, DC: American Society for Microbiology.

Gonzalez, J. M. \& Saiz-Jimenez, C. (2005). A simple fluorimetric method for the estimation of DNA-DNA relatedness between closely related microorganisms by thermal denaturation temperatures. Extremophiles 9, 75-79.

Goodfellow, M. (1992). The family Nocardiaceae. In The Prokaryotes, 2nd edn, pp. 1188-1213. Edited by A. Balows, H. G. Trüper, M. Dworkin, W. Harder \& K. H. Schleifer. New York: Springer.

Goodfellow, M. (1998). Nocardia and related genera. In Topley \& Wilson's Microbiology \& Microbial Infections, 9th edn, vol. 2, pp. 463489. Edited by A. Balows \& B. I. Duerden. London: Edward Arnold.

Goodfellow, M. \& Lechevalier, M. P. (1989). Genus Nocardia. Trevisan 1889, $9^{\mathrm{AL}}$. In Bergey's Manual of Systematic Bacteriology, vol. 2, pp. 1458-1471. Edited by S. T. Williams, M. E. Sharpe \& J. G. Holt. Baltimore: Williams \& Wilkins.

Goodfellow, M., Isik, K. \& Yates, E. (1999). Actinomycete systematics: an unfinished synthesis. Nova Acta Leopold 312, 47-82.

Gordon, R. E. (1967). The taxonomy of soil bacteria. In The Ecology of Soil Bacteria, pp. 293-321. Edited by T. R. G. Gray \& D. Parkinson. Liverpool: Liverpool University Press.

Gordon, R. E. \& Mihm, J. M. (1957). A comparative study of some strains received as nocardiae. J Bacteriol 73, 15-27.

Gordon, R. E. \& Minm, J. M. (1962). The type species of the genus Nocardia. J Gen Microbiol 27, 1-10. 
Gordon, R. E., Barnett, D. A., Handerhan, J. E. \& Pang, C. H.-N. (1974). Nocardia coeliaca, Nocardia autotrophica, and the nocardin strain. Int J Syst Bacteriol 24, 54-63.

Huß, V. A. R., Festl, H. \& Schleifer, K. H. (1983). Studies on the spectrometric determination of DNA hybridisation from renaturation rates. Syst Appl Microbiol 4, 184-192.

Igarashi, M., Hayashi, C., Homma, Y., Hattori, S., Kinoshita, N., Hamada, M. \& Takeuchi, T. (2000). Tubelactomicin A, a novel 16membered lactone antibiotic, from Nocardia sp. I. Taxonomy, production, isolation and biological properties. J Antibiot (Tokyo) 53, 1096-1101.

Isik, K., Chun, J., Hah, Y. C. \& Goodfellow, M. (1999). Nocardia salmonicida nom. rev., a fish pathogen. Int J Syst Bacteriol 49, 833837.

Jones, K. L. (1949). Fresh isolates of actinomycetes in which the presence of sporogenous aerial mycelia is a fluctuating characteristic. J Bacteriol 57, 141-145.

Jukes, T. H. \& Cantor, C. R. (1969). Evolution of protein molecules. In Mammalian Protein Metabolism, vol. 3, pp. 21-132. Edited by H. N. Munro. New York: Academic Press.

Kageyama, A., Yazawa, K., Nishimura, K. \& Mikami, Y. (2005). Nocardia anaemiae sp. nov. isolated from an immunocompromised patient and the first isolation report of Nocardia vinacea from humans. Nippon Ishinkin Gakkai Zasshi 46, 21-26.

Kämpfer, P. \& Kroppenstedt, R. M. (1996). Numerical analysis of fatty acid patterns of coryneform bacteria and related taxa. Can $J$ Microbiol 42, 989-1005.

Komaki, H., Nemoto, A., Tanaka, Y., Takagi, H., Yazawa, K., Mikami, Y., Shigemori, H., Kobayashi, J., Ando, A. \& Nagata, Y. (1999). Brasilicardin A, a new terpenoid antibiotic from pathogenic Nocardia brasiliensis: fermentation, isolation and biological activity. J Antibiot (Tokyo) 52, 13-19.

Kumar, S., Tamura, K. \& Nei, M. (2004). MEGA3: integrated software for molecular evolutionary genetics analysis and sequence alignment. Brief Bioinform 5, 150-163.

Lechevalier, M. P. (1976). The taxonomy of the genus Nocardia: some light at the end of the tunnel? In The Biology of the Nocardiae, pp. 1-33. Edited by M. Goodfellow, G. H. Brownell \& J. A. Serrano. London: Academic Press.

Lechevalier, M. P. \& Lechevalier, H. A. (1980). The chemotaxonomy of actinomycetes. In Actinomycete Taxonomy (Special Publication no. 6), pp. 227-291. Edited by A. Dietz \& J. Thayer. Arlington, VA: Society for Industrial Microbiology.

Maldonado, L., Hookey, J. V., Ward, A. C. \& Goodfellow, M. (2000). The Nocardia salmonicida clade, including descriptions of Nocardia cummidelens sp. nov., Nocardia fluminea sp. nov. and Nocardia soli sp. nov. Antonie van Leeuwenhoek 78, 367-377.
McNeil, M. M. \& Brown, J. M. (1994). The medically important aerobic actinomycetes: epidemiology and microbiology. Clin Microbiol Rev 7, 357-417.

Minnikin, D. E., Hutchinson, I. G., Caldicott, A. B. \& Goodfellow, M. (1980). Thin layer chromatography of methanolysates of mycolic acid-containing bacteria. J Chromatogr A 188, 221-233.

Orchard, V. A. (1979). Effect of sewage sludge additions on Nocardia in soil. Soil Biol Biochem 11, 217-220.

Orchard, V. A. (1981). The ecology of Nocardia and related taxa. Zentralbl Bakteriol 11 (Suppl.), 167-180.

Orchard, V. A., Goodfellow, M. \& Williams, S. T. (1977). Selective isolation and occurrence of Nocardiae in soil. Soil Biol Biochem 9, 233-238.

Saintpierre, D. (2001). Identification de souches originales d'actinomycétes isolées de sols ultramafiques de Nouvelle-Calédonie. Caractérisation chimique de quelques antibiotiques produits. $\mathrm{PhD}$ thesis, Institut National Polytechnique de Toulouse, France (in French).

Saitou, N. \& Nei, M. (1987). The neighbor-joining method: a new method for reconstructing phylogenetic trees. Mol Biol Evol 4, 406425.

Sasser, M. (1990). Identification of bacteria by gas chromatography of cellular fatty acids, MIDI Technical Note 101. Newark, DE: MIDI Inc.

Shirling, E. B. \& Gottlieb, D. (1966). Methods for characterization of Streptomyces species. Int J Syst Bacteriol 16, 313-340.

Stackebrandt, E., Rainey, F. A. \& Ward-Rainey, N. L. (1997). Proposal for a new hierarchic classification system, Actinobacteria classis nov. Int J Syst Bacteriol 47, 479-491.

Staneck, J. L. \& Roberts, G. D. (1974). Simplified approach to identification of aerobic actinomycetes by thin-layer chromatography. Appl Microbiol 28, 226-231.

Thompson, J. D., Higgins, D. G. \& Gibson, T. J. (1994). CLUSTAL_W: improving the sensitivity of progressive multiple sequence alignment through sequence weighting, position-specific gap penalties and weight matrix choice. Nucleic Acids Res 22, 4673-4680.

Trevisan, v. (1889). I Generi e le Specie delle Batteriacee. Milan: Zanaboni \& Gabuzzi.

Wang, Y., Zhang, Z. S., Ruan, J. S., Wang, Y. M. \& Ali, S. M. (1999). Investigation of actinomycete diversity in the tropical rainforests of Singapore. J Ind Microbiol Biotechnol 23, 178-187.

Williams, S. T., Goodfellow, M., Alderson, G., Wellington, E. M. H., Sneath, P. H. A. \& Sackin, M. J. (1983). Numerical classification of Streptomyces and related genera. J Gen Microbiol 129, 1743-1813.

Wu, C., Lu, X., Qin, M., Wang, Y. \& Ruan, J. (1989). Analysis of menaquinone compound in microbial cells by HPLC. Microbiology (English translation of Mikrobiologiia) 16, 176-178. 